\title{
Modelling of the estimated contributions of different sub-watersheds and sources to phosphorous export and loading from the Dongting Lake watershed, China
}

\author{
Ying Hou • Weiping Chen • Yuehua Liao • \\ Yueping Luo
}

Received: 23 January 2017 / Accepted: 12 October 2017 / Published online: 3 November 2017

(C) Springer International Publishing AG 2017

\begin{abstract}
Considerable growth in the economy and population of the Dongting Lake watershed in Southern China has increased phosphorus loading to the lake and resulted in a growing risk of lake eutrophication. This study aimed to reveal the spatial pattern and sources of phosphorus export and loading from the watershed. We applied an export coefficient model and the DillonRigler model to quantify contributions of different subwatersheds and sources to the total phosphorus (TP) export and loading in 2010. Together, the upper and lower reaches of the Xiang River watershed and the Dongting Lake Area contributed $60.9 \%$ of the TP exported from the entire watershed. Livestock husbandry appeared to be the largest anthropogenic source of TP, contributing more than $50 \%$ of the TP exported from each secondary sub-watersheds. The actual TP loading to the lake in 2010 was $62.9 \%$ more than the permissible annual TP loading for compliance with the Class III water quality standard for lakes. Three primary subwatersheds - the Dongting Lake Area, the Xiang River,
\end{abstract}

Electronic supplementary material The online version of this article (https://doi.org/10.1007/s10661-017-6293-8) contains supplementary material, which is available to authorized users.

Y. Hou $\cdot$ W. Chen $(\bowtie)$

State Key Laboratory of Urban and Regional Ecology, Research Center for Eco-Environmental Sciences, Chinese Academy of Sciences, Beijing 100085, China

e-mail: wpchen@rcees.ac.cn

Y. Liao • Y. Luo

Hunan Province Environmental Monitoring Centre,

Changsha 410014, China and the Yuan River watersheds - contributed $91.2 \%$ of the total TP loading. As the largest contributor among all sources, livestock husbandry contributed nearly $50 \%$ of the TP loading from the Dongting Lake Area and more than $60 \%$ from each of the other primary subwatersheds. This study provides a methodology to identify the key sources and locations of TP export and loading in large lake watersheds. The study can provide a reference for the decision-making for controlling $\mathrm{P}$ pollution in the Dongting Lake watershed.

Keywords Export coefficient model · Dillon-Rigler model $\cdot$ Phosphorous $\cdot$ Livestock husbandry $\cdot$ Transport coefficients

\section{Introduction}

An increasing number of lakes in China have been facing eutrophication problems in recent decades (Liu et al. 2015; Ma and Wang 2015). Exacerbation of the lake eutrophication problem was mainly due to increases in lake water nitrogen $(\mathrm{N})$ and phosphorus $(\mathrm{P})$ caused by human activities (Bennett et al. 2001; Conley et al. 2009). Following effective control of point source pollution (e.g., treatment of urban sewage and industrial wastewater), the contribution of pollutants from nonpoint sources in lake watersheds (e.g., agriculture, atmospheric deposition, and rural population) has become the major cause of water quality degradation in many of China's lakes (Ma et al. 2011; Ma and Wang 2015; Wang et al. 2015). Many of these lakes are located in 
watersheds heavily impacted by agricultural activities and dominated by rural and urban population (Liu et al. 2013; Ma and Wang 2015). Consequently, N and P are exported in fertilizer lost from crop farms, animal excreta from distributed livestock farms, and wastes produced by rural inhabitants. When discharged into receiving waters via irrigation or rainfall-runoff, these nutrients cause lake eutrophication, degradation of the lake water environment, and loss of biodiversity in lake ecosystems (Ma et al. 2011; Wu et al. 2012; Chen et al. 2013). Because $P$ is the limiting nutrient in freshwaters, the control of $\mathrm{P}$ input is crucial to preventing freshwater lake eutrophication (Bennett et al. 2001; Johnes et al. 2007; Matias and Johnes 2012). Knowledge about P export and loading from different regions and sources in a lake watershed is important in developing policy for the protection of lake water quality and the sustainable management of the watershed environment.

The export coefficient model (ECM) was originally developed in North America for estimating nutrient export in watersheds and nutrient input to lakes and streams (Omernik 1976; Reckhow and Simpson 1980; Johnes 1996). The export coefficients describe the rates at which nutrients are lost from each source to the surface drainage network and are often derived from literature and in some studies from field experiments (Johnes 1996). The ECM has been proved reliable for modeling nutrient pollution on a watershed scale (Winter and Duthie 2000; Beckert et al. 2011; Ma and Wang 2015; Rodrigues-Filho et al. 2015; Wu et al. 2015; Ma et al. 2016). Requiring fewer data inputs (mainly the quantity of nutrient sources) and using fewer parameters (mainly the export coefficients and transport coefficients of nutrient sources) than deterministic models, the ECM method is simpler than process-based models (Ma et al. 2011; Matias and Johnes 2012). Although the ECM does not simulate complex processes of nutrient generation, transport and transformation, the method has acceptable precision, especially on a large scale, and is particularly useful in areas where few observed data are available (Liu et al. 2009; Matias and Johnes 2012; Wu et al. 2015). Early studies using the ECM predicted nutrient export only as a function of different land use types, such as cropland, grassland, and woodland (Beaulac and Reckhow 1982; Johnes 1996). Some later studies considered other non-point sources (e.g., livestock husbandry, rural households, and atmospheric deposition) and point sources (e.g., sewage treatment works and industrial wastewater discharges) and estimated the contributions from different sources or regions to nutrient export (Matias and Johnes 2012; Chen et al. 2013; Liu et al. 2013; Yilmaz and Sivri 2014). These studies indicated that farming, residential population, and livestock breeding are usually the major sources of $\mathrm{N}$ and $\mathrm{P}$ in watersheds and that different watersheds have distinct predominant sources. Some researchers modified the ECM by incorporating influential factors, such as precipitation and terrain, in the model and tested the suitability of the improved model in empirical studies (Ding et al. 2010; Wang et al. 2015). In addition to revealing the nutrient emission patterns in past periods, the ECM has been used to simulate future nutrient pollution status under different watershed management scenarios. Used as a predictive tool, the ECM has been shown to be helpful in determining optimal watershed management strategies.

Empirical nutrient balance models have been widely used to predict in-lake nutrient concentrations using the nutrient loading to lakes (Dillon and Rigler 1974; Johnes et al. 2007). In some cases, these models can be used to back-calculate "permissible" anthropogenic load from the "permissible" nutrient concentration (as defined by water quality regulations); the permissible load can further be expressed as allowable human activity (Dillon and Rigler 1974). Among the best-known empirical models are those published by Dillon and Rigler (1974), Vollenweider (1975), and the OECD (1982). The models combine nutrient budget data with data describing lake morphometry and the water budget, and have been shown to be effective for oligotrophic and mesotrophic lakes (Dillon and Rigler 1974; Bennion et al. 2005; Johnes et al. 2007). Some studies compared the predicted results of these models with the observed data, indicating that the Dillon-Rigler model (Dillon and Rigler 1974) can produce results that are close to observations in different cases (Pulatsü and Aydin 1997; Johnes et al. 2007). Based on the prediction of P loading, the Dillon-Rigler model has been further used to estimate the ecological carrying capacity of lakes (e.g., the carrying capacity of cage aquaculture production in lakes (Mhlanga 2013; David et al. 2015). In addition, studies on several lakes in China showed the suitability of the Dillon-Rigler model in predicting in-lake nutrient concentrations and estimating the nutrient loading to lakes (Gao 2014; Li et al. 2014).

Through our review of existing studies, we found that although many studies have estimated contributions from different sources or regions to nutrient export in 
watersheds (Matias and Johnes 2012; Chen et al. 2013; Liu et al. 2013; Yilmaz and Sivri 2014), few studies have investigated the contributions from sources or regions in watersheds to lake nutrient loading.

Dongting Lake is the second largest freshwater lake in China and is located in the middle reach of the Yangtze River. This lake has been experiencing an increase in nutrient loading and a growing risk of lake water eutrophication due to large growth in the economy and population of the surrounding watershed. In addition, the self-purification capacity of the lake has been reduced because inflow water volume to the lake has been significantly decreased by the impoundment of the Three Gorges Dam (Zhang 2007). As P is the limiting nutrient for oligotrophic and mesotrophic freshwater lakes, the control of P loading is crucial for preventing eutrophication of the lake. However, the contributions to $\mathrm{P}$ export and loading from different sources and regions are still unknown for the Dongting Lake watershed, which prevents policy makers from implementing effective measures for controlling P pollution.

Therefore, in this study, we aimed to fill the knowledge gap about the patterns of $\mathrm{P}$ export and loading from the Dongting Lake watershed and examine whether the export coefficient method and the Dillon-Rigler model could be combined to estimate contributions from different sources and regions to $\mathrm{P}$ loading. The specific objectives of this study were (1) to reveal the contributions from different sources and sub-watersheds to the TP exported from the Dongting Lake watershed, (2) to determine the permissible and actual TP loading to the Dongting Lake, and (3) to estimate the contributions from different sources and sub-watersheds to the TP loading of the Dongting Lake.

\section{Study area}

The Dongting Lake $\left(111^{\circ} 53^{\prime}-113^{\circ} 05^{\prime} \mathrm{E} ; 28^{\circ} 44^{\prime}-29\right.$ ${ }^{\circ} 35^{\prime} \mathrm{N}$ ) has a surface area of approximately $2625 \mathrm{~km}^{2}$ and a volume of about $167 \times 10^{8} \mathrm{~m}^{3}$, with a mean water depth of $6.39 \mathrm{~m}$ and a maximum depth of $23.5 \mathrm{~m}$ (1995, Dou and Jiang 2000). The Dongting Lake receives recharge from three flood discharge channels of the Yangtze River in the northwest (the Songzi, Taiping, and Ouchi channels) and four major tributaries, the Xiang River and Zi River from the south and the Yuan River and Li River from the west (Fig. 1). The mean annual residence time of the lake is 20 days, and the mean annual sediment import and export of the lake (1953-2010) are 13,363 × $10^{4}$ and $3930 \times 10^{4} \mathrm{t}$, respectively. The Dongting Lake is characterized by strong intra-annual fluctuations in water level and water storage capacity. Its water level and water storage capacity in the wet season are about 1.14-1.64 times and 17-31 times, respectively, of that in the dry season (Tian et al. 2017). The surface area of the Dongting Lake can be divided into three parts, the East Dongting Lake ( $\left.1300 \mathrm{~km}^{2}\right)$, the South Dongting Lake $\left(\sim 900 \mathrm{~km}^{2}\right)$, and the West Dongting Lake $\left(\sim 340 \mathrm{~km}^{2}\right)$. The lake water is discharged to the Yangtze River from the outlet of the East Dongting Lake.

The watershed of the Dongting Lake is the largest lake watershed in China, covering an area of $262 \times 10^{3} \mathrm{~km}^{2}$, of which $82.7 \%$ is in Hunan province. The Dongting Lake watershed consists of five primary sub-watersheds, including four watersheds of the four major tributaries and the Dongting Lake Area. The watersheds of the Xiang, Zi, and Yuan Rivers are divided into upper reach and lower reach sections (Fig. 1b). The eastern, southern, and western parts of the Dongting Lake watershed are mainly mountainous areas; the middle part of the watershed is mostly covered by hills, basins, and valleys; and the northern part is the Dongting Lake plain. The watershed has a sub-tropical monsoon climate with an average annual temperature of $16-19{ }^{\circ} \mathrm{C}$ and an average annual precipitation of 1100-1700 mm. Forest and farmland are the predominant land use types in the watershed. Forest is mostly distributed in the eastern, southern, and western parts of the watershed, and farmland covers most of the Dongting Lake plain in the north of the watershed (Fig. 1b). The urban and rural populations of the Dongting Lake watershed were 30 million and 41 million in 2010, respectively. Most (71\%) of the urban population and $58 \%$ of the rural population were distributed in the Xiang River watershed and the Dongting Lake Area in 2010.

The area of the five primary sub-watersheds - the Xiang, Zi, Yuan, and Li River watersheds and the Dongting Lake Area-are $94.2 \times 10^{3}, 25.7 \times 10^{3}$, $90.4 \times 10^{3}, 17.9 \times 10^{3}$, and $33.7 \times 10^{3} \mathrm{~km}^{2}$, respectively. The total population of the five primary sub-watersheds were $3234 \times 10^{4}, 957 \times 10^{4}, 1222 \times 10^{4}, 355 \times 10^{4}$, and $1322 \times 10^{4}$ persons, respectively, in 2010 . The five primary sub-watersheds had livestock (cattle and pigs) numbers of $2671 \times 10^{4}, 801 \times 10^{4}, 826 \times 10^{4}, 264 \times 10^{4}$, 
Fig. 1 a Land use classification of the Dongting Lake Area and the location of the water quality monitoring sites in 2010. The Dongting Lake Area is a butterfly-shaped basin including the Dongting Lake as the core, the alluvial plain in the east, south and north of the lake, and the hilly area around the plain. b Land use classification of the Dongting Lake watershed in 2010, main tributaries of the Dongting Lake, and boundaries of the secondary sub-watersheds: A Upper reach of the Xiang River watershed; B Lower reach of the Xiang River watershed; $C$ Upper reach of the Zi River watershed; D Lower reach of the Zi River watershed; E Upper reach of the Yuan River watershed; F Lower reach of the Yuan River watershed; G Li River watershed; and H Dongting Lake Area. c Location of the Dongting Lake watershed in China

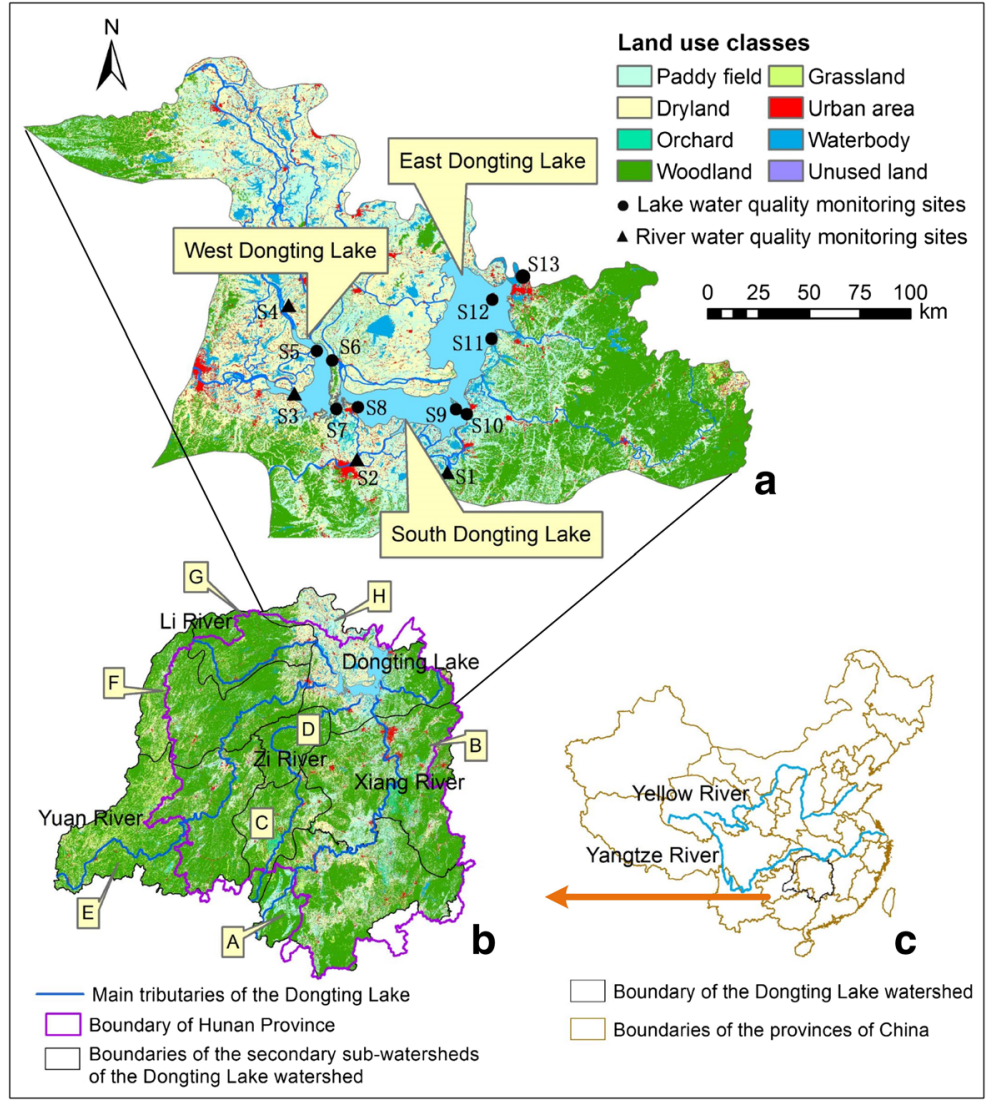

and $970 \times 10^{4}$ heads, respectively, in 2010. Moreover, the mean annual water discharge from the five primary sub-watersheds to the Dongting Lake (1950-2000) are $696 \times 10^{8}, 232 \times 10^{8}, 398 \times 10^{8}, 133 \times 10^{8}$, and $83 \times 10^{8} \mathrm{~m}^{3}$, respectively.

\section{Methods}

Water quality data collection

Water quality data were collected for the major tributaries of the Dongting Lake and the eastern, southern, and western sections of the lake from four river water quality monitoring sites, eight lake water quality monitoring sites, and a site at the outlet of the lake (Fig. 1a). The four river water quality monitoring sites are located close to the mouth of the four major tributaries of the Dongting Lake, respectively. Among the eight lake water quality monitoring sites, two are located in East Dongting Lake, three in South
Dongting Lake, and three in West Dongting Lake. The water quality data in the form of mean annual TP concentration for 2010 were derived from an official institution-the Hunan Province Environmental Monitoring Centre. The sampling, sample processing, and water quality analyzing were conducted by this institution. The institution collected water samples monthly in 2010. The samples were collected from a depth of $0.5 \mathrm{~m}$ at the monitoring sites, and each site had three sampling points (left, middle, right). TP concentration was determined using molybdenum-antimony anti-spectrophotometric method after filtration through cellulose acetate membranes $(0.45 \mu \mathrm{m})$, following the guidelines of the Chinese national standard-Environmental Quality Standards for Surface Water (GB3838-2002). Furthermore, the mean annual TP concentrations at the monitoring sites were derived by averaging the monthly TP concentrations at the respective sites (see Table A1 in the Online Source for the data). Based on the data obtained from the official 
institution, we calculated the mean annual concentrations of TP for the East, South, and West Dongting Lake and the entire lake for 2010.

\section{TP export estimation}

\section{Export coefficient model}

According to existing studies on the water pollutant emissions in the Dongting Lake watershed, the major sources for TP export from the watershed include land use activities, urban population, rural population, livestock husbandry, aquaculture, industrial wastewater, and atmospheric deposition. Land use is classified as paddy field, dryland, orchard, woodland, grassland, urban area, and unused land. Wastewater discharges from the urban population include domestic wastewater discharged into sewage treatment systems as well as wastewater that is not discharged to such systems (but rather is directly discharged into the environment). Livestock includes cattle and pigs.

The export coefficient model was originally developed in North America to estimate nutrient inputs to a waterbody from land uses (Omernik 1976; Reckhow and Simpson 1980; Beaulac and Reckhow 1982). Thereafter, the model was widely used in empirical studies and continuously modified in the process of application. Modifications included the incorporation of various nutrient sources such as human population, livestock and poultry husbandry, industrial wastewater discharge, and atmospheric deposition (Johnes 1996; Liu et al. 2009; Ma and Wang 2015). A general form of the model is:

$L_{j}=\sum_{i=1}^{m} E_{i j} A_{i}+D$

where $j$ is the type of nutrient (TP in this study), $i$ is the type of nutrient source in a region, $L_{j}$ is total export of nutrient $j$ from all sources in the region, $E_{i j}$ is the export coefficient of nutrient $j$ from source $i$, and $A_{i}$ is the quantity of source $i$ (the area of different land use types in the region, or the number of a livestock type, or number of people, or the production volume of aquaculture, or the volume of industrial wastewater). $D$ is the nutrient input from atmospheric deposition to the region, which is calculated as:

$D=d \times a$ where $d$ is the atmospheric nutrient deposition rate in $\mathrm{kg}$ / $\mathrm{km}^{2} /$ year and $a$ is the area of the region.

\section{Determination of export coefficients and transport coefficients}

The determination of the export coefficients for different nutrient sources of a specific region is crucial when building an export coefficient model for the region. Up to now, a large number of studies have provided export coefficients for different nutrient sources in different research areas. Referring to existing studies, we determined the TP export coefficients for the nutrient sources of the Dongting Lake watershed. In addition, we determined the transport coefficients of different TP sources (Table 1). The selection and calculation of the coefficients are specified below.

The TP export coefficients of paddy field $(0.063 \mathrm{t}$ / $\mathrm{km}^{2} /$ year$)$, dryland $\left(0.11 \mathrm{t} / \mathrm{km}^{2} /\right.$ year $)$, and orchard $\left(0.072 \mathrm{t} / \mathrm{km}^{2} /\right.$ year$)$ were calculated from the coefficients provided by the Fertilizer Loss Coefficient Handbook that was compiled based on the First National Census on Pollution Sources (The Office of the Leading Group on the First National Census on Pollution Sources 2007). This handbook gives the export coefficients of nutrients in different forms (including TP) for different farming patterns in different agricultural regions of China. The nutrient export coefficients in the handbook were obtained based on field sampling and monitoring.

The TP export coefficients of woodland, grassland, urban area, and unused land also were selected with reference to existing studies. Ma et al. (2011), Liu et al. (2009), and Zhao et al. (2012) provide the TP export coefficients of different land use types for the Three Gorges Reservoir Area of Hubei Province, the upper reach of the Yangtze River Basin, and the Xitiaoxi catchment in the lower reach of the Yangtze River Basin, respectively. Located in the middle reach of the Yangtze River Basin, the Dongting Lake watershed has a similar climate to the study areas of these three studies. In addition, these four land use types have similar topographical characters between the Dongting Lake watershed and the other three regions. Therefore, we selected the TP export coefficient of woodland $\left(0.015 \mathrm{t} / \mathrm{km}^{2} /\right.$ year) for the Dongting Lake watershed referring to $\mathrm{Ma}$ et al. (2011) and Zhao et al. (2012), determined the coefficient of grassland $\left(0.040 \mathrm{t} / \mathrm{km}^{2} /\right.$ year $)$ based on Liu et al. (2009) and Ma et al. (2011), used the coefficient of urban area $\left(0.18 \mathrm{t} / \mathrm{km}^{2} /\right.$ year $)$ provided by $\mathrm{Ma}$ 
Table 1 Export coefficients and transport coefficient of total phosphorus (TP) sources used for the Dongting Lake watershed. The coefficients were selected or calculated from the coefficients given by published literature. Transport coefficient denotes the ratio of stream TP loading to TP export (adapted from Hou et al. 2017)

\begin{tabular}{|c|c|c|c|c|c|}
\hline \multirow[t]{2}{*}{ TP source } & \multirow[t]{2}{*}{ Unit } & \multicolumn{2}{|c|}{ Export coefficient } & \multicolumn{2}{|c|}{ Transport coefficient } \\
\hline & & Value & Reference & $\begin{array}{l}\text { Value } \\
\text { (unitless) }\end{array}$ & Reference \\
\hline Dryland & $\mathrm{t} / \mathrm{km}^{2} /$ year & 0.11 & \multirow{3}{*}{$\begin{array}{l}\text { The Office of the Leading Group on the First } \\
\text { National Census on Pollution Sources } \\
\text { (2007) }\end{array}$} & 0.25 & \multirow{7}{*}{$\begin{array}{l}\text { Liu et al. (2009); Pang and Lu } \\
\text { (2010) }\end{array}$} \\
\hline Paddy field & $\mathrm{t} / \mathrm{km}^{2} /$ year & 0.063 & & 0.25 & \\
\hline Orchard & $\mathrm{t} / \mathrm{km}^{2} /$ year & 0.072 & & 0.25 & \\
\hline Grassland & $\mathrm{t} / \mathrm{km}^{2} /$ year & 0.040 & Liu et al. (2009); Ma et al. (2011) & 0.25 & \\
\hline Woodland & $\mathrm{t} / \mathrm{km}^{2} /$ year & 0.015 & Ma et al. (2011); Zhao et al. (2012) & 0.25 & \\
\hline Urban area & $\mathrm{t} / \mathrm{km}^{2} /$ year & 0.18 & Ma et al. (2011) & 0.25 & \\
\hline Unused land & $\mathrm{t} / \mathrm{km}^{2} /$ year & 0.036 & Liu et al. (2009); Ma et al. (2011) & 0.25 & \\
\hline $\begin{array}{l}\text { Urban population } \\
\text { (connected to } \\
\text { sewage } \\
\text { treatment plant) }\end{array}$ & $\mathrm{mg} / \mathrm{L}$ & 1.00 & $\begin{array}{l}\text { Ministry of Environmental Protection of } \\
\text { China and General Administration of } \\
\text { Quality Supervision, Inspection and } \\
\text { Quarantine of China (2002a) }\end{array}$ & 1 & $\begin{array}{l}\text { Pang and Lu (2010); } \\
\text { Alexander et al. (2002) }\end{array}$ \\
\hline $\begin{array}{l}\text { Urban population } \\
\text { (not connected } \\
\text { to sewage } \\
\text { treatment plant) }\end{array}$ & $\times 10^{-4} \mathrm{t} /$ person/year & 2.75 & $\begin{array}{l}\text { The Office of the Leading Group on the First } \\
\text { National Census on Pollution Sources } \\
\text { (2007) }\end{array}$ & 0.8 & $\begin{array}{l}\text { Pang and Lu (2010); Li et al. } \\
\quad(2014)\end{array}$ \\
\hline Rural population & $\times 10^{-4} \mathrm{t} /$ person/year & 2.14 & Ma et al. (2011) & 0.7 & Li et al. (2014) \\
\hline $\begin{array}{l}\text { Cattle } \\
\text { Pigs }\end{array}$ & $\begin{array}{l}\times 10^{-4} \mathrm{t} / \mathrm{head} / \text { year } \\
\times 10^{-4} \mathrm{t} / \mathrm{head} / \text { year }\end{array}$ & $\begin{array}{r}44.53 \\
7.25\end{array}$ & \multirow{2}{*}{$\begin{array}{l}\text { The Office of the Leading Group on the First } \\
\text { National Census on Pollution Sources } \\
\text { (2007) }\end{array}$} & $\begin{array}{l}0.6 \\
0.6\end{array}$ & $\begin{array}{l}\text { Pang and Lu (2010); Li et al. } \\
\text { (2014) }\end{array}$ \\
\hline Aquaculture & $\mathrm{g} / \mathrm{kg} /$ year & 3.55 & & 1 & $\begin{array}{l}\text { The Office of the Leading } \\
\text { Group on the First } \\
\text { National Census on } \\
\text { Pollution Sources (2007) }\end{array}$ \\
\hline $\begin{array}{l}\text { Industrial } \\
\text { wastewater }\end{array}$ & $\mathrm{mg} / \mathrm{L}$ & 0.57 & Zhang (2007) & 0.8 & $\begin{array}{l}\text { Pang and Lu (2010); Li et al. } \\
\quad \text { (2014) }\end{array}$ \\
\hline $\begin{array}{r}\text { Atmospheric } \\
\text { deposition }\end{array}$ & $\mathrm{kg} / \mathrm{km}^{2} /$ year & 205.85 & Yang et al. (2007); Yu et al. (2011) & $\begin{array}{l}0.25 \text { or } \\
1^{\mathrm{a}}\end{array}$ & Pang and $\mathrm{Lu}(2010)$ \\
\hline
\end{tabular}

${ }^{\mathrm{a}} 0.25$ for atmospheric TP deposition on land and 1 for atmospheric TP deposition on waterbodies

et al. (2011), and obtained the coefficient of unused land $\left(0.036 \mathrm{t} / \mathrm{km}^{2} /\right.$ year $)$ by averaging the coefficients given by Liu et al. (2009) and Ma et al. (2011).

According to the "Discharge standard of pollutants for municipal wastewater treatment plants (GB18918 2002)", the highest permitted effluent TP concentration of wastewater from sewage treatment plants is $1.0 \mathrm{mg} / \mathrm{L}$ (mean daily value) for the first, "level-B" standard. This concentration was selected as the TP export coefficient for the urban population connected to sewage treatment plants. This fraction of urban population (75\%) for each district and county was converted to the volume of domestic wastewater. To do so, this fraction of urban population was multiplied by the mean annual domestic wastewater discharge per person $\left(56.2 \mathrm{~m}^{3} /\right.$ person/year and $43.8 \mathrm{~m}^{3} /$ person/year for Hunan and Guizhou Provinces, respectively). The "Handbook of Pollutant Emission Coefficients for Urban Population" (The Office of the Leading Group on the First National Census on Pollution Sources 2007) gives the TP export coefficient of the domestic wastewater not treated and directly discharged into the environment for different prefectures 
of China. Based on this handbook, we calculated the TP export coefficient $\left(2.75 \times 10^{-4} \mathrm{t} /\right.$ person/year $)$ for the proportion of the urban population not connected to centralized sewage treatment $(25 \%$ of the total urban population for each district and county). In addition, the TP export coefficient for the rural population $\left(2.14 \times 10^{-4} \mathrm{t} /\right.$ person/year) was selected based on Ma et al. (2011). The study area of Ma et al. (2011) was the Three Gorges Reservoir Area of Hubei Province, which has similar climate and topographical characteristics, as well as a close socio-economic development level, to the Dongting Lake watershed.

The TP export coefficients for cattle $\left(44.53 \times 10^{-4} \mathrm{t} /\right.$ head/year), pigs $\left(7.25 \times 10^{-4} \mathrm{t} /\right.$ head/year $)$, and aquaculture $(3.55 \mathrm{~g} / \mathrm{kg} /$ year $)$ were calculated from the coefficients provided by the "Handbook of Pollutant Emission Coefficients for Livestock and Poultry Husbandry" compiled based on the First National Census on Pollution Sources (The Office of the Leading Group on the First National Census on Pollution Sources 2007). This handbook gives the TP export coefficients of the animal husbandry for the major livestock and poultry types for different regions of China. In terms of cattle and pig husbandry, the export coefficients for the animals at different growing stages raised on farms, in scattered communities, and by households were provided. As for aquaculture, the handbook gives the TP export coefficients for different fish species raised in freshwater ponds and net cages.

Zhang (2007) suggested the TP export coefficient of industrial wastewater $(0.57 \mathrm{mg} / \mathrm{L})$ for the Dongting Lake Area. This coefficient was used for the entire Dongting Lake watershed in our study. Zheng et al. (2014) found that the atmospheric TN deposition rate for the Dongting Lake watershed was close to that for the Taihu Lake Area. Furthermore, Yang et al. (2007) and Yu et al. (2011) reported the atmospheric TP deposition rate for the Taihu Lake Area. Therefore, we determined the atmospheric TP deposition rate for the Dongting Lake watershed $\left(205.85 \mathrm{~kg} / \mathrm{km}^{2} /\right.$ year $)$ by averaging the deposition rates provided by these two studies.

Export coefficients in this study reflect the process of nutrient export to the environment with runoff. Nutrients are partly removed from runoff during their transport from land to river by processes such as retention by vegetation, soil infiltration, sediment adsorption and deposition, and biochemical processes (Wu et al. 2012). Therefore, transport coefficient, which indicates the ratio of nutrient loading to streams to nutrient export, is necessary for estimating nutrient loading to waterbody. Generally, diffuse sources have much smaller transport coefficients than point sources because export nutrient from diffuse sources are partly removed by landscape in the transportation process, and in contrast, point source is much more directly connected to waterbody (Alexander et al. 2002). Many studies have suggested transport coefficients for different TP sources. As land use is a typical diffuse source, the transport coefficient of land use types are relatively small and are suggested to be $0.1-0.3$ (Pang and $\mathrm{Lu} 2010$ ) and 0.25 (Liu et al. 2009). Therefore, we set the transport coefficients of all the land use types to 0.25 in this study (Table 1). Considering that the transport coefficients of point sources are expected to be large (1 or close to 1 ), we determined the coefficients in our study by referring to several exiting studies as urban population connected to sewage treatment plant (1.0), urban population not connected to sewage treatment plant (0.8), aquaculture (1.0), and industrial wastewater (0.8) (Alexander et al. 2002; Li et al. 2014; Pang and Lu 2010; The Office of the Leading Group on the First National Census on Pollution Sources 2007). Although rural population is a diffuse source of nutrient pollution when scatteredly distributed, its transport coefficient is usually larger than that of land use, since rural residential areas are more congregated than other land use types and are usually distributed close to river networks. The Dongting Lake watershed is experiencing a trend that rural residents' housing is congregating accompanied by concentrating waste discharges. Consequently, rural population is shifting from a diffuse source to a point source in the watershed. Considering this fact and referring to Li et al. (2014), we set the transport coefficient of rural population to 0.7 . Livestock husbandry has been transforming from a diffuse source to a point source in large parts of China because of the transition of animal production from household scale to industrial farm scale since the 1990s. As a consequence, animal manure is currently often not used on land, but mainly discharged to nearby water systems (Bai et al. 2016; Strokal et al. 2016). Therefore, the transport coefficient of animal husbandry should be large. According to Pang and Lu (2010) and $\mathrm{Li}$ et al. (2014), the value of transport 
coefficient of livestock husbandry is 0.6 . We presumed this value to be reasonable and used it in our study. The transport coefficient of atmospheric deposition was set to 0.25 for TP deposited on land because the transportation process of nutrient export from this source is the same as that from land use. For the TP deposited directly on waterbody from atmosphere, the transport coefficient was set to 1 .

\section{Estimation of TP export}

Hunan Province and Guizhou Province cover 82.7 and $11.6 \%$ of the area of the Dongting Lake watershed, respectively. In addition, three counties (Songzi, Gongan, and Shishou) of Hubei Province are located in the Dongting Lake watershed. Therefore, we calculated the TP export from the districts and counties located in both Hunan or Guizhou Provinces and the Dongting Lake watershed, as well as from Songzi, Gongan, and Shishou counties, using the export coefficient model. The data for the population, livestock husbandry, aquaculture, and industrial wastewater discharge of the districts and counties for 2010 were derived from the Statistical Yearbook of Hunan Province (2011), the Statistical Yearbook of Guizhou Province (2011), and the Statistical Yearbook of Jinzhou Prefecture (2011). The spatial data describing land use for the Dongting Lake watershed for 2010 were obtained from the Research Center for Eco-Environmental Sciences, Chinese Academy of Sciences (see Table 4 in the Appendix for the details of the data). We calculated the total TP export for each secondary sub-watershed by summing the TP export from the districts and counties in each respective sub-watershed. Furthermore, we estimated the export intensity of TP and the contribution from each anthropogenic nutrient source (not including atmospheric deposition) to the total export of TP for each secondary sub-watershed. The calculations were conducted and the results were mapped using ArcGIS 10 (Environmental Systems Research Institute, Redlands, CA, USA).

TP loading calculation

A model of the nutrient balance in lakes was developed by Dillon and Rigler (1974). The model is based on the assumption that the annual mass of nutrient loading to a lake equals the sum of the mass of the nutrient retained in the lake and the mass leaving the lake via the outflow.
The model has been used to estimate the nutrient loading to different lakes in empirical studies (Pulatsü and Aydin 1997; Johansson and Nordvarg 2002; David et al. 2015). An expression of the model is as follows (Gao 2014):

$W=\frac{C_{S} \times S \times H \frac{Q_{\text {in }}}{V}}{1-R}$

where $W$ is the permissible or actual annual nutrient loading to a lake in t/year, $C_{S}$ is the mean annual concentration of a nutrient in the lake meeting the water quality standard for lakes or the actual mean annual concentration of a nutrients in the lake $(\mathrm{mg} / \mathrm{L}), S$ is the lake surface area in $\mathrm{km}^{2}, H$ is the mean depth of the lake in meter, $Q_{\text {in }}$ is the inflow water volume of the lake in $10^{8} \mathrm{~m}^{3} /$ year, $V$ is the lake volume in $10^{8} \mathrm{~m}^{3}$, and $R$ is the nutrient retention coefficient.

When $C_{S}$ is the mean annual concentration of a nutrient in a lake meeting the water quality standard for lakes, $W$ is the permissible annual nutrient loading to the lake; when $C_{S}$ is the actual mean annual concentration of a nutrient in a lake, $W$ is the actual annual nutrient loading to the lake. We used the model to estimate both the permissible and actual annual TP loadings to the Dongting Lake in 2010.

According to the Chinese national standard-Environmental Quality Standards for Surface Water (GB3838-2002), the TP concentrations in lakes meeting the Class III and IV standards for lake water quality are $\leq 0.05 \mathrm{mg} / \mathrm{L}$ and $\leq 0.1 \mathrm{mg} / \mathrm{L}$, respectively. The mean annual concentration of TP in 2010 for the entire Dongting Lake was determined to be $0.081 \mathrm{mg} / \mathrm{L}$ by averaging the mean annual concentrations of TP at all water quality monitoring sites in the lake in 2010. The surface area of the Dongting Lake in 2010 was determined by referring to Yu et al. (2016) and Lai et al. (2012). The data on the inflow and outflow water volume of the Dongting Lake for 2010 were derived from the Hunan Water Resources Bulletin (2010) (http://www.hnsw.com.cn/Default.aspx). The mean depth of the lake equals the lake volume divided by the lake surface area. The lake volume for 2010 was estimated using the regression function established by Tan (2013) as follows:

$V=-1.119 \times 10^{-5} S^{2}+0.115 S-0.987 A S$

where $V$ is the volume of the Dongting Lake in $10^{8} \mathrm{~m}^{3}, S$ is the lake surface area in $\mathrm{km}^{2}$, and $A S$ is 
the accumulated sediment quantity in the lake during 1951 to 2010 in $10^{8}$ t, which was calculated by adding the sediment quantity in 2009 and 2010 to the accumulated sediment quantity during 1951 to 2008. For 2009 and 2010, the annual sediment accumulation equaled the quantity of sediment imported into the lake subtracted by the quantity of sediment exported from the lake each year. The data on the accumulated sediment quantity during 1951 to 2008 in the lake was provided by Tan (2013). The data on the sediment imported into and exported from the lake in 2009 and 2010 were obtained from the Sediment Bulletin of the Yangtze River (2009 and 2010) (http://www.cjh.com. $\mathrm{cn} /$ pages/nsgb.html).

The retention coefficient of TP was calculated using the equation provided by Kirchner and Dillon (1975) as follows:

$R=0.426 e^{-0.271 q_{a}}+0.574 e^{-0.00949 q_{a}}$

$q_{a}=\frac{Q_{o u t}}{S}$

where $Q_{\text {out }}$ is the outflow water volume of the lake in $10^{8} \mathrm{~m}^{3} /$ year, and $S$ is the lake surface area in $\mathrm{km}^{2}$.

Estimation of TP loading from different sub-watersheds and sources

We calculated the TP loading from the five primary sub-watersheds of the Dongting Lake watershed. In addition, we estimated the stream-lake transport coefficient of TP (i.e., the ratio of lake TP loading to stream TP loading) for the sub-watersheds. Furthermore, the contribution from each source to lake TP loading was calculated for each primary subwatershed.

The TP loading from the four major tributaries (Xiang River, Zi River, Yuan River, and Li River) to the Dongting Lake in 2010 was calculated as follows:

$$
T P_{i n(i)}=C_{T P(i)} \times Q_{i n(i)}
$$

where $T P_{\text {in }(i)}$ is the TP loading from tributary $i$ to the Dongting Lake (t), $C_{\mathrm{TP}(i)}$ is the mean annual TP concentration in the tributary at the water quality monitoring site located close to the mouth of the tributary in $2010(\mathrm{mg} / \mathrm{L})$, and $Q_{\mathrm{in}(i)}$ is the flow volume of tributary $i$ in $2010\left(10^{6} \mathrm{~m}^{3}\right)$.

The TP loading from the Dongting Lake Area to the lake in 2010 was calculated as follows:

$T P_{i n(\mathrm{LA})}=W_{\text {LakeTP}}-T P_{i n(\mathrm{XR})}-T P_{i n(\mathrm{ZR})}-T P_{i n(\mathrm{YR})}-T P_{i n(\mathrm{LR})}$

where $T P_{\text {in(LA) }}$ denotes the TP loading from the Dongting Lake Area to the lake in 2010 (t); $W_{\text {LakeTP }}$ means the actual annual TP loading to the Dongting Lake in 2010 calculated using the Dillon-Rigler model (t); $T P_{\text {in(XR) }}, T P_{\text {in(ZR) }}, T P_{\text {in(YR), }}$, and $T P_{\text {in(LR) }}$ denote the TP loading from the Xiang River, Zi River, Yuan River, and Li River to the Dongting Lake in 2010, respectively (t).

The TP loading to streams from the primary subwatersheds of the Dongting Lake watershed in 2010 was calculated using the following equation:

$T P_{R(i)}=\sum_{j=1}^{n} E_{i j \mathrm{TP}} C_{R(j)}$

where $T P_{R(i)}$ is the TP loading to streams from primary sub-watershed $i(\mathrm{t}), E_{i j \mathrm{TP}}$ is the TP export from source $j$ in primary sub-watershed $i(\mathrm{t})$, and $C_{R(j)}$ is the transport coefficient for source $j$ (dimensionless, see Table 1). The TP sources include urban population, rural population, livestock husbandry, aquaculture, industrial wastewater, land use, and atmospheric deposition. The TP export from each primary sub-watershed was calculated by summing the TP export from the districts or counties, which was estimated using the export coefficient model in each sub-watershed.

The TP in streams consists of three fractions. One fraction is retained in streams before being transported to a lake or to the sea owing to physical and biochemical processes, such as sedimentation, absorption, and assimilation by aquatic organisms (Chen et al. 2010); the second fraction returns to land via water consumptions by people; and the third fraction is transported to the lake or the sea via the outflows of the streams. The stream-lake transport coefficients of TP for different primary sub-watersheds of the Dongting Lake watershed were calculated using the following equation:

$C_{\mathrm{LTP}(i)}=\frac{T P_{i n(i)}}{T P_{R(i)}}$

where $C_{\mathrm{LTP}(i)}$ is the stream-lake transport coefficient of TP for primary sub-watershed $i(0-1$, dimensionless), $\mathrm{TP}_{\mathrm{in}(i)}$ is the TP loading from tributary $i$ to the Dongting 
Lake ( $\mathrm{t}$ ), and $\mathrm{TP}_{R(i)}$ is the TP loading to streams from primary sub-watershed $i(\mathrm{t})$.

Furthermore, we calculated the contribution from each source to the TP loading of the lake for each primary sub-watershed as:

$P_{i j}=E_{i j} C_{R(j)} C_{\mathrm{LTP}(i)}$

where $P_{i j}$ is the contribution from source $j$ to the TP loading of the Dongting Lake from primary subwatershed $i(\mathrm{t}), E_{i j}$ is the TP export from source $j$ in primary sub-watershed $i(\mathrm{t}), C_{R(j)}$ is the transport coefficient for source $j\left(0-1\right.$, dimensionless), and $C_{L T P(i)}$ is the stream-lake transport coefficient of TP for primary subwatershed $i(0-1$, dimensionless $)$.

\section{Results and discussion}

TP export from different secondary sub-watersheds

The estimation using the export coefficient model shows that the three highest secondary sub-watersheds for TP export were the upper and lower reaches of the Xiang River watershed and the Dongting Lake Area. These three sub-watersheds exported $1.75 \times 10^{4} \mathrm{t}(18.8 \%)$, $2.16 \times 10^{4} \mathrm{t}(23.2 \%)$, and $1.78 \times 10^{4} \mathrm{t}(19 \%) \mathrm{TP}$, respectively, and together accounted for $60.9 \%$ of the total TP exported from the Dongting Lake watershed in 2010 (Fig. 2). Four other secondary sub-watersheds made much smaller contributions to TP export $(<$ $10 \%)$. These sub-watersheds are, in descending order, the upper reach of the $\mathrm{Zi}$ River watershed $\left(0.81 \times 10^{4} \mathrm{t}\right.$, $8.7 \%$ ), the lower reach of the Yuan River watershed $\left(0.61 \times 10^{4} \mathrm{t}, 6.5 \%\right)$, the Li River watershed $\left(0.49 \times 10^{4} \mathrm{t}, 5.2 \%\right)$, and the lower reach of the $\mathrm{Zi}$ River watershed $\left(0.46 \times 10^{4} \mathrm{t}, 4.9 \%\right)$. Among the secondary sub-watersheds, the Dongting Lake Area $\left(0.528 \mathrm{t} / \mathrm{km}^{2}\right)$ and the upper reach of the Zi River $\left(0.516 \mathrm{t} / \mathrm{km}^{2}\right)$ were estimated to have the greatest TP export intensity. In contrast, the three secondary sub-watersheds in the western part of the Dongting Lake watershed (i.e., the upper and lower reaches of the Yuan River watershed and the Li River watershed) were estimated to have much smaller TP export intensity $\left(0.233 \mathrm{t} / \mathrm{km}^{2}\right.$, $0.172 \mathrm{t} / \mathrm{km}^{2}$, and $0.273 \mathrm{t} / \mathrm{km}^{2}$, respectively). The TP export from the upper and lower reaches of the Xiang River watershed and the Dongting Lake Area, which have large areas of valleys and plains, were estimated to be much greater than that from the other secondary subwatersheds because these three sub-watersheds had much greater quantities of the major TP sources. For example, the farmland area, the population, and the number of pigs of these three sub-watersheds accounted for 65,65 , and $68 \%$, respectively, of the total quantity of each of these sources in the Dongting Lake watershed (see Fig. 1). Other studies have also found that the valleys and plains of a watershed are where agricultural production and populations are mainly distributed and have high TP exports (Ma and Wang 2015; Hwang et al. 2016; Wang et al. 2016). As these three secondary subwatersheds are much more populated and developed than the other regions of the Dongting Lake watershed, it is crucial for environmental managers to implement effective measures for controlling $\mathrm{P}$ export in these regions.

\section{TP export from different sources}

According to the modeling, livestock husbandry ranked the first among all the anthropogenic sources in terms of TP export from each of the secondary sub-watersheds of the Dongting Lake watershed in 2010 (Figs. 3 and 4). Livestock production was estimated to contribute more than $70 \%$ of the TP exported from the upper reach of the Xiang River watershed, the upper and lower reaches of the $\mathrm{Zi}$ River watershed, and the upper reach of the Yuan River watershed. Livestock husbandry was also estimated to contribute more than $60 \%$ of the TP exported from the lower reach of the Xiang River watershed, the lower reach of the Yuan River watershed, and the Li River watershed, and more than $50 \%$ from the Dongting Lake Area. Livestock husbandry appeared to be the key contributor to TP export because the number of pigs raised in Hunan Province was considerably large $\left(40.5 \times 10^{6}\right.$ head $)$, which ranked third among all provinces of China and accounted for $8.7 \%$ of the pigs in China at the end of 2010. In the Dongting Lake Area, aquaculture was estimated to rank second among the sources in terms of TP export (22.1\%). Rural population and land use were also important sources. The proportion of TP export from the rural population was estimated to be approximately $10 \%$ of the total TP exported from all sources in all secondary subwatersheds. The contribution from land use to the TP export was estimated to be greater than $10 \%$ for 
Fig. 2 The composition, intensity, and total quantity of the total phosphorus (TP) export from the secondary sub-watersheds of the Dongting Lake watershed in 2010. A Upper reach of the Xiang River watershed; B Lower reach of the Xiang River watershed; C Upper reach of the Zi River watershed; D Lower reach of the $\mathrm{Zi}$ River watershed; E Upper reach of the Yuan River watershed; F Lower reach of the Yuan River watershed; G Li River watershed; and H Dongting Lake Area

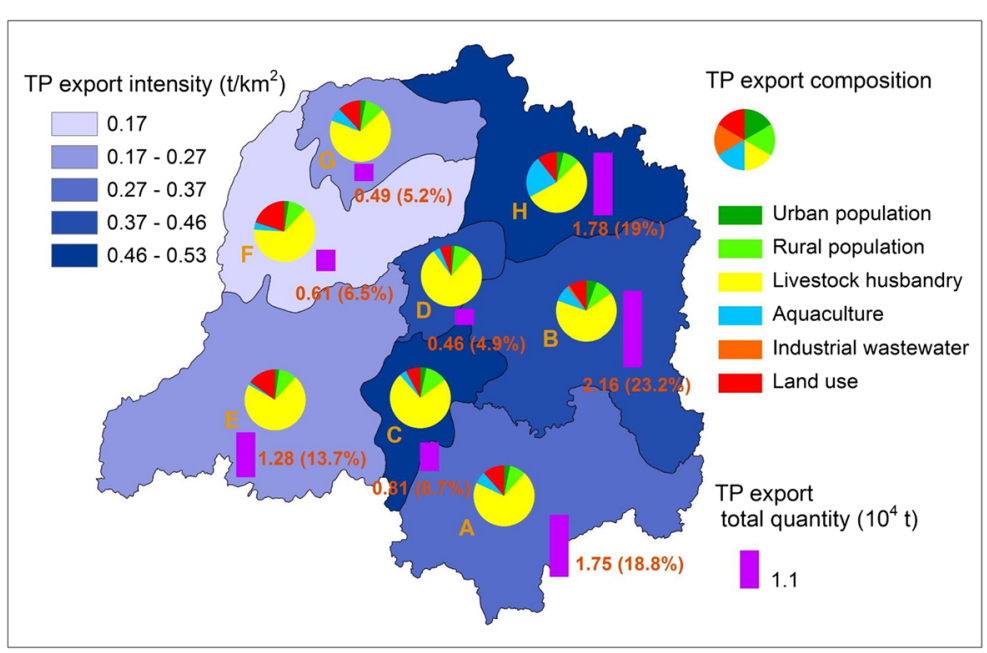

the upper reach of the Xiang River watershed, the Li River watershed, and the Dongting Lake Area, and more than $15 \%$ for the upper and lower reaches of the Yuan River watershed. Industrial wastewater was estimated to contribute the least among all sources to TP export from the secondary sub-watersheds (1.35\% for the lower reach of the Xiang River watershed and less than $1 \%$ for all other secondary sub-watersheds). The next least important TP contributor was urban population, which was estimated to contribute $5.6 \%$ of the TP exported from the lower reach of the Xiang River watershed and less than $4 \%$ of the TP export from each of the other secondary sub-watersheds.

The above results indicate that the TP export in the Dongting Lake watershed appeared to mainly come from agricultural sources, of which livestock husbandry was predominant and should be the particular focus of TP export controls. In the past decades, industrial and domestic point source pollution has been effectively abated in many regions in China because of a rapid increase in the number of wastewater treatment plants. As a result, contributions from agricultural sources have become a major cause of water quality degradation in
Fig. 3 Total phosphorus (TP) export from different sources in the upper and lower reaches of the Xiang River watershed and the upper and lower reaches of the $\mathrm{Zi}$ River watershed in 2010

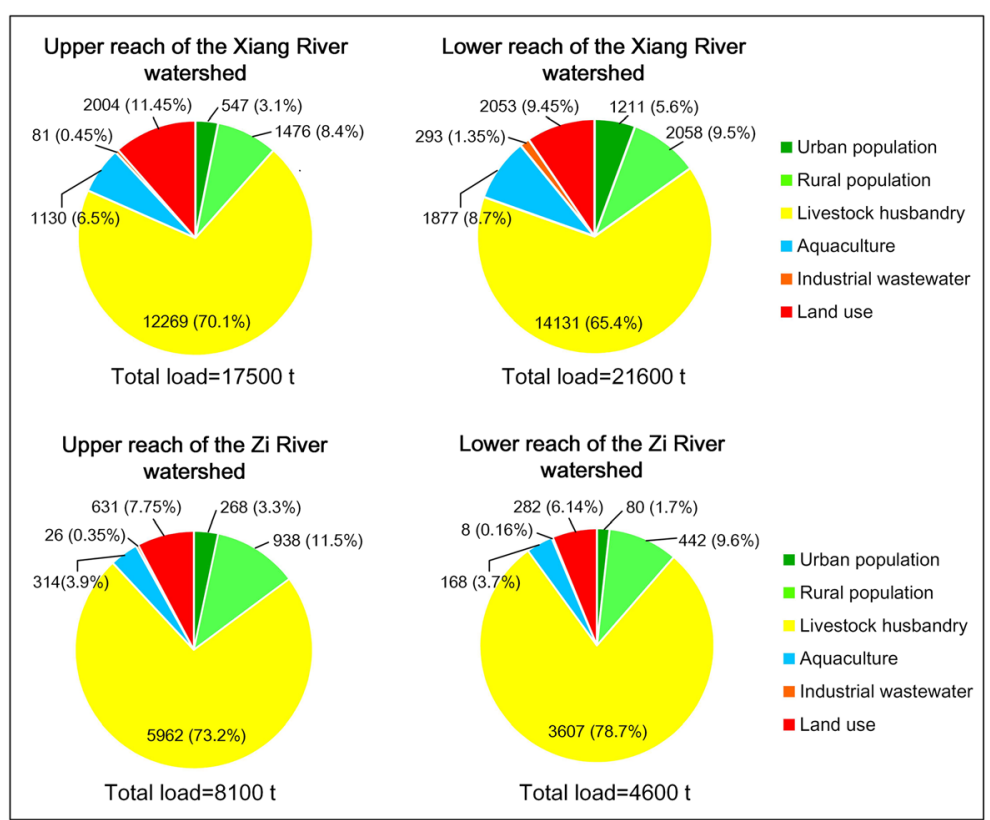


Fig. 4 Total phosphorus (TP) export from different sources in the upper and lower reaches of the Yuan River watershed, the $\mathrm{Li}$ River watershed, and the Dongting Lake Area in 2010

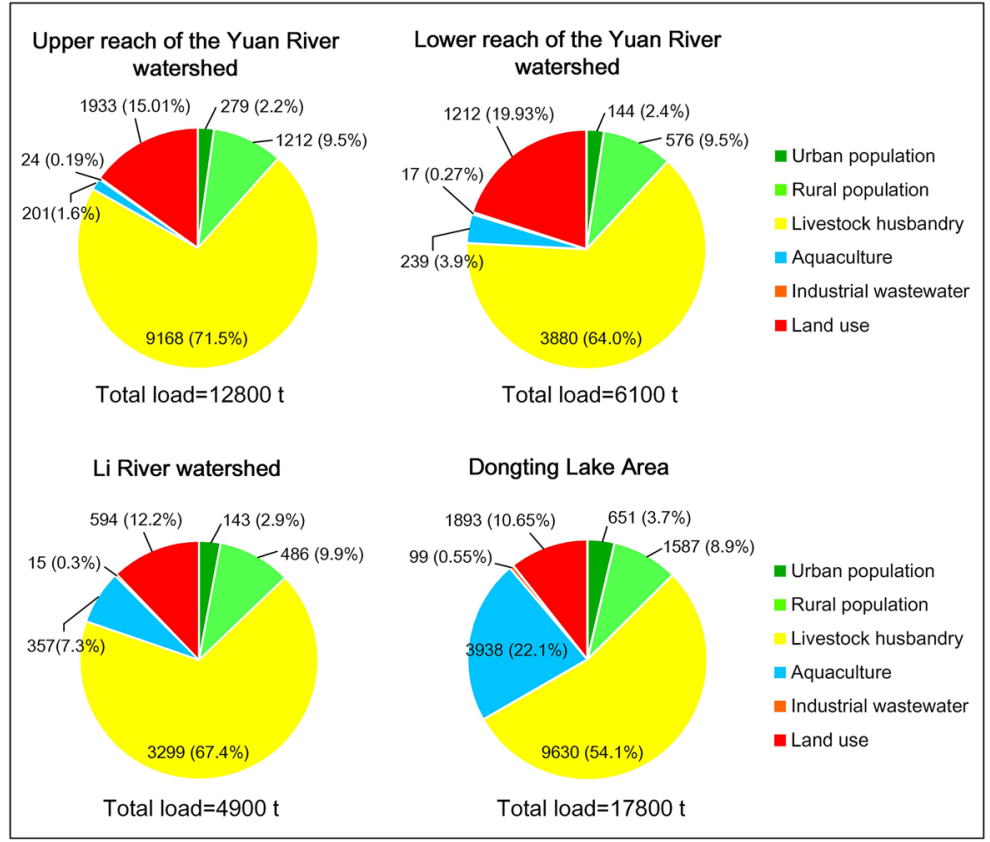

China (Ma et al. 2011; Chen et al. 2013; Liu et al. 2015). Effective control of water pollutant emission from agricultural sources is a key task for water environmental management in human-impacted watersheds in China. As for lake watersheds, the various governments should make special efforts to reduce $\mathrm{P}$ emission and mitigate lake eutrophication (Bennett et al. 2001; Matias and Johnes 2012). In addition, the results suggest that the source composition of a given pollutant can differ across regions of a watershed (also see Matias and Johnes 2012). For example, aquaculture was estimated to make a much greater contribution to the TP export from the Dongting Lake Area than from each of the other secondary sub-watersheds in this study. Therefore, watershed managers should identify the most significant pollutant sources for different regions of a watershed, so as to develop corresponding strategies to effectively reduce pollutant emission.

The stream-lake transport coefficient and loading of TP

The stream-lake transport coefficients of TP in the primary sub-watersheds of the Dongting Lake watershed were calculated using Eq. 9. The Dongting Lake Area was estimated to have the largest streamlake TP transport coefficient (0.92) among the primary sub-watersheds, which means most of the TP loading to streams in the Dongting Lake Area appeared to be transported to the Dongting Lake in 2010. Therefore, it is critical for environmental managers of the regions in the Dongting Lake Area, such as the policy makers of the counties in the watershed, to reduce the TP export from the key sources in the watershed. Moreover, the environmental managers can abate TP loading to the Dongting Lake by increasing the retention of TP by implementing controls such as vegetated buffer strips along the flow paths from the P sources to the streams. The stream-lake transport coefficients of TP for the other primary sub-watersheds were estimated to be, in descending order, the Li River watershed

Table 2 Values for variables in the Dillon-Rigler model for the Dongting Lake in 2010

\begin{tabular}{llc}
\hline Variable & Unit & Value \\
\hline$S:$ lake surface area & $\mathrm{km}^{2}$ & 2528.1 \\
$H:$ mean depth of the lake & $\mathrm{m}$ & 6.18 \\
$Q_{\text {in }}$ : inflow water volume of the lake & $10^{8} \mathrm{~m}^{3}$ year $^{-1}$ & 2865.9 \\
$Q_{\text {out }}$ : outflow water volume of the lake & $10^{8} \mathrm{~m}^{3}$ year $^{-1}$ & 2799 \\
$V:$ lake volume & $10^{8} \mathrm{~m}^{3}$ & 156.1 \\
$R:$ nutrient retention coefficient & & 0.201 \\
\hline
\end{tabular}


Table 3 The permissible and actual annual loading of total phosphorus (TP) to the Dongting Lake in 2010. The permissible loading is based on the Chinese national standard - Environmental
Quality Standards for Surface Water (GB3838-2002) (Ministry of Environmental Protection of China and General Administration of Quality Supervision, Inspection and Quarantine of China 2002b)

\begin{tabular}{lllll} 
Pollutant & $\begin{array}{l}\text { Water quality } \\
\text { standard }\end{array}$ & $\begin{array}{l}\text { Permissible annual } \\
\text { loading(t/year })\end{array}$ & $\begin{array}{l}\text { Actual annual loading } \\
(\mathrm{t} / \mathrm{year})\end{array}$ & $\begin{array}{l}\text { Actual annual loading relative to permissible } \\
\text { annual loading }\end{array}$ \\
\hline $\mathrm{TP}$ & $\begin{array}{c}\text { Class III } \\
(\leq 0.05 \mathrm{mg} / \mathrm{L}) \\
\text { Class IV } \\
(\leq 0.1 \mathrm{mg} / \mathrm{L})\end{array}$ & 17,928 & 29,203 & $162.9 \%$ \\
& 35,856 & 29,203 & $81.4 \%$ \\
\hline
\end{tabular}

(0.40), the Yuan River watershed (0.37), the Xiang River watershed (0.27), and the Zi River watershed (0.12). The low stream-lake transport coefficient for the $\mathrm{Zi}$ River watershed indicates that only a small fraction of the TP loading to the river network in the watershed appeared to be transported to the Dongting Lake in 2010. With respect to the TP loading, the actual annual loading to the Dongting Lake was estimated to be $29.2 \times 10^{3} \mathrm{t}$ in 2010 , which was $62.9 \%$ more than the permissible annual loading $\left(17.9 \times 10^{3} \mathrm{t}\right)$ that would meet the Class III standard for lake water quality and $81.4 \%$ of the permissible annual loading $\left(35.9 \times 10^{3} \mathrm{t}\right)$ that would meet the Class IV standard for lake water quality (GB3838-2002) (Tables 2 and 3). According to the "Water Environmental Functional Demarcation for Hunan Main Surface River" (DB43/023-2005) issued by the Environmental Protection Department of Hunan Province, most of the waterbody of the Dongting Lake should meet the Class III standard for lake water quality. Thus, the TP loading should be reduced by $38.6 \%\left(11.3 \times 10^{3} \mathrm{t} / \mathrm{year}\right)$ of the actual annual loading in 2010 .

The contributions from different sub-watersheds and sources to TP loading

The Dongting Lake Area was estimated to rank first among the primary sub-watersheds of the Dongting Lake watershed in terms of TP loading $\left(11.0 \times 10^{3} \mathrm{t}\right)$ to the lake in 2010 . This region was followed in rank by two other primary sub-watersheds, the Xiang River watershed $\left(6.6 \times 10^{3} \mathrm{t}\right)$ and the Yuan River watershed $\left(4.0 \times 10^{3} \mathrm{t}\right)$. The TP loading from these three sub-watersheds was estimated to account for $91.2 \%$ in the total TP loading from the Dongting Lake watershed (Fig. 5). The $\mathrm{Zi}$
River watershed and the Li River watershed were estimated to contribute only $0.9 \times 10^{3} \mathrm{t}(3.9 \%)$ and $1.2 \times 10^{3} \mathrm{t}(4.9 \%)$ to the TP loading, respectively. The most important source of TP loading was estimated to be livestock husbandry (nearly $50 \%$ for the Dongting Lake Area and more than $60 \%$ for the other four primary sub-watersheds). Rural population was estimated to be another major source of $\mathrm{P}$, contributing around $10 \%$ of the TP loading from all anthropogenic sources for all primary sub-watersheds. In addition, aquaculture was estimated to contribute around $12 \%$ of the TP loading from the Xiang River watershed and the Li River watershed and $33 \%$ of the TP loading from the Dongting Lake Area. Industrial wastewater was estimated to be a minor contributor of $\mathrm{P}$, contributing only $1.2 \%$ of the TP loading from the Xiang River watershed and less than $1 \%$ of $\mathrm{TP}$ from the other primary subwatersheds.

An interesting phenomenon is that the contribution rates of the Xiang, $\mathrm{Zi}$, Yuan, and $\mathrm{Li}$ River watersheds to TP loading were estimated to be smaller than the contributions to TP export. In contrast, the Dongting Lake Area appeared to have a greater contribution rate to TP loading than to TP export (see Figs. 2 and 5). For example, the Xiang River watershed and the Dongting Lake Area were estimated to contribute 42 and $19 \%$ of the TP export from the Dongting Lake watershed, respectively. However, the contribution from the Xiang River watershed to the TP loading was estimated to be lower $(27.7 \%)$ and that from the Dongting Lake Area was higher $(46.6 \%)$. This phenomenon can be explained by two major reasons. First, the contribution of aquaculture $(22.1 \%)$ to the TP export from the Dongting Lake Area was much greater than that from the other primary sub-watersheds $(1.4-8.7 \%)$ 


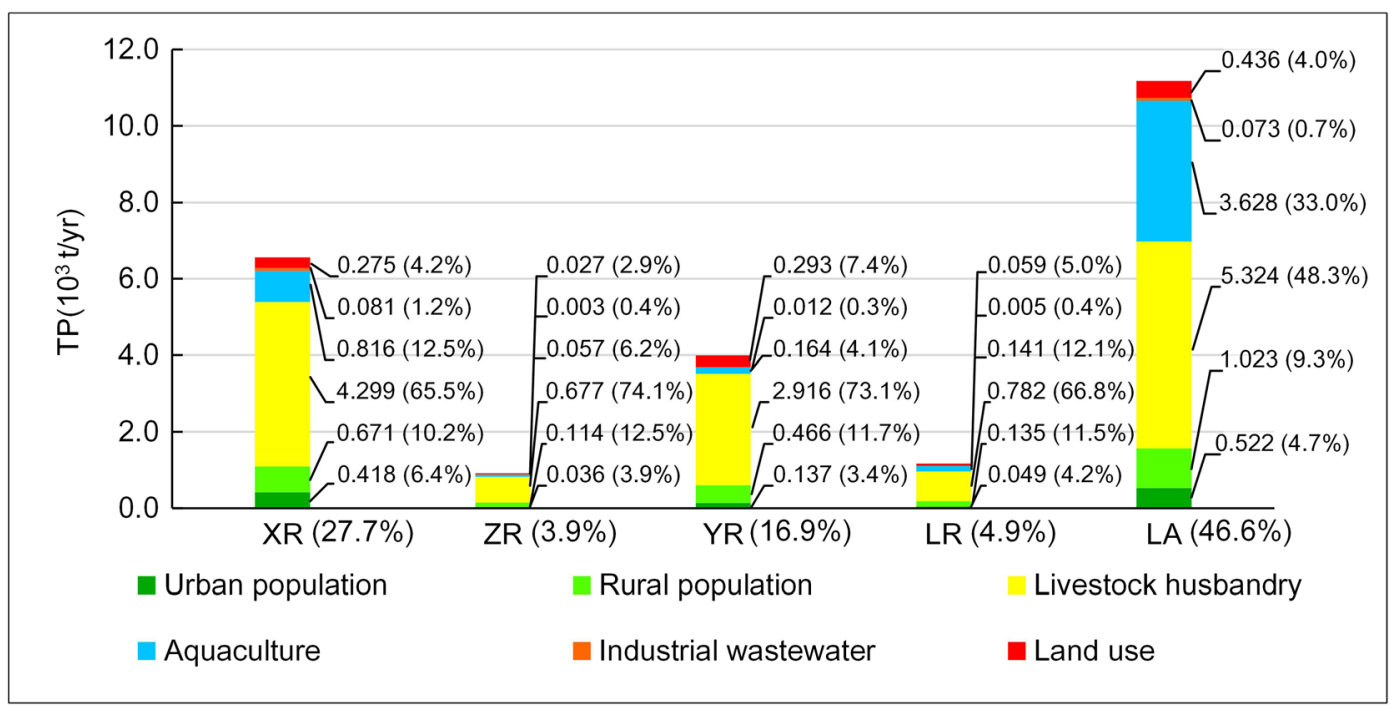

Fig. 5 The quantity and composition of the lake TP loading from the primary sub-watersheds of the Dongting Lake watershed. XR (Xiang River watershed); ZR (Zi River watershed); YR (Yuan River watershed); LR (Li River watershed); LA (Dongting Lake

because of the large-scale fish farming in the Dongting Lake. Compared to other sources, whose TP exports are ameliorated to different degrees during the transport process via surface runoff to the river network (see the transport coefficients in Table 1, and Mourad et al. 2006; Pang and Lu 2010; Li et al. 2014), the TP export from aquaculture directly enters waterbodies. Second, the instream TP retention in the Dongting Lake Area was much less than that in the other four primary sub-watersheds, resulting in a larger fraction of instream TP from the Dongting Lake Area reaching the lake. Previous studies have also found that the in-stream TP retention rates are considerably different among different watersheds (Alexander et al. 2002; Mourad et al. 2006; Chen et al. 2010). The above-demonstrated phenomenon indicates that sources with short connections to waterbodies and the sub-watersheds having low in-stream TP retention rates should be prioritized when making TP pollution mitigation policies for lake watersheds.

The livestock husbandry in the Xiang River watershed, the Yuan River watershed, and the Dongting Lake Area were estimated to make a large contribution to the TP loading to the Dongting Lake. Therefore, it is critical for the local governments to reduce the TP export from livestock production in these
Area). The percentages following the abbreviation of the subwatershed names mean the contributions of each sub-watershed to the total TP loading from the entire Dongting Lake watershed

three primary sub-watersheds. As pigs and cattle are the major livestock types in the Dongting Lake watershed, the local governments should make effective policies to reduce the number of pigs and cattle in the watershed. For example, the governments can make policies encouraging the pig and cattle farmers to substitute current livestock husbandry practices with other production patterns (Qin et al. 2011). As P is mostly discharged with the excreta of pigs and cattle, it is important for the animal farmers to enhance the treatment of the excreta (Liu et al. 2013). The governments can make rules requiring livestock farmers to build treatment facilities for livestock excreta, as well as subsidize the livestock farmers for building and operating the facilities (Wilkins 2008).

\section{Uncertainty analysis}

In the results of our study, only the TP loadings from the four major tributaries of the Dongting Lake were determined from actual observations of TP concentration and water flow volume at gauging stations. Other results, including TP export, TP loading from different sources, and permissible and actual annual lake TP loading, were generated based on modeling. The modeling process brings 
uncertainties, which are mainly related to model suitability, coefficients credibility, and data uncertainty (Hou et al. 2013).

The export coefficient model is proved to be plausible in different regions in the world by many studies, although it was originally developed in North America. A high suitability of the model to study areas mainly depends on using plausible export coefficients (the plausibility of coefficients in our study is demonstrated in the following paragraph). The Dillon-Rigler model is a simplified mass balance model also built in North America. The simplifications in the development of the model inevitably bring about uncertainties. Up to now, the model has been applied in some regions out of North America. Several studies proved the plausibility of the modeling results by the facts that the results are close to other mainstreaming mass balance models (Johansson and Nordvarg 2002; Gao 2014), and the modeling results are validated by observed data (Johansson and Nordvarg 2002). When applying the Dillon-Rigler model to the Dongting Lake, we calculated the retention coefficient of TP using the empirical equation (Eq. 5a in this article) proposed by Kirchner and Dillon (1975), instead of using real data on lake input and output of TP. As this equation was fitted by data of some lakes in North America, it may be questionable to be applied to the Dongting Lake.

Export coefficients and transport coefficients strongly influence the final results in our study. As the coefficient values were determined based on literature, uncertainties emerge when applying the values to the Dongting Lake watershed. We attempted to reduce the uncertainties in the determination of the coefficients through (1) using coefficients obtained by sampling and measurement work in the field by official institutions in recent years; (2) selecting coefficients from existing studies in which the study areas have similar geographic, climatic, and socio-economic characteristics to the Dongting Lake watershed; and (3) referring to different literature for some coefficients. The First National Census on Pollution Sources was implemented under the organization of the State Council of China in 2008. Based on this census, a handbook providing updated export coefficients of pollutants (including TP) from different sources in different regions of China was compiled. In this study, the TP export coefficients of paddy field, dryland, orchard, urban population not connected to centralized sewage treatment, cattle, pigs, and aquaculture were determined from the handbook. As the coefficients provided by the handbook were determined based on sampling, measurement, and investigation throughout the entire year of 2008 , the TP export coefficients we derived should reflect the reality of the year and are plausible to be applied in this study for 2010. In addition, we determined the TP export coefficients of woodland, grassland, urban areas, unused land, rural population, industrial wastewater, and atmospheric deposition referring to several pieces of literature in which the study areas have similar physical and socio-economic characteristics to the Dongting Lake watershed (e.g., the three Gorges Reservoir Area of Hubei Province, Ma et al. 2011). Therefore, the coefficients provided in these literature should be appropriate to be applied to the Dongting Lake watershed. Among the limited literature reporting transport coefficients, Alexander et al. (2002) demonstrate the factors influencing the values of the coefficients, and three pieces of literature in Chinese-Liu et al. (2009), Pang and Lu (2010), and Li et al. (2014)-provide transport coefficients of different sources. Referring to these literature, we determined the transport coefficients in this study. Although uncertainties exist in the use of the coefficients, we followed a reasonable principle that sources more like point sources have larger transport coefficients and those more like diffuse sources have smaller transport coefficients.

Data uncertainty in this study is mainly related to the use of mean annual TP concentrations. A highly plausible method to calculate annual TP loadings from the tributaries to the Dongting Lake is to sum up the production of mean daily (or monthly) TP concentrations at the river water quality monitoring sites and daily (or monthly) flow volumes of the tributaries for the entire year. However, as we were not able to obtain daily or monthly water quality data, we calculated the annual TP loadings by multiplying mean annual TP concentrations and annual flow volumes of the tributaries (Eq. 6). As the river plains in the study area are flooded by high water in the rainy season due to the monsoon climate, the calculations of annual TP loadings using the equation may not be appropriate. 
The uncertainties related to models, coefficients, and data in this study lead to uncertain results. For example, the TP loading from the Dongting Lake Area was calculated based on a mass balance assumption (Eq. 7). The uncertainties in the calculation of the annual TP loadings from the tributaries as demonstrated in the preceding paragraph can result in an inaccurate value of TP loading from the Dongting Lake Area. Consequently, the stream-lake transport coefficient of TP for the Dongting Lake Area calculated by Eq. 9 may not be close to the coefficient in the real world. Although uncertainties exist in the modeling process and the results of our study, the most significant result that animal husbandry is the prominent anthropogenic TP source in the Dongting Lake watershed reflects the reality. In our study, livestock husbandry and aquaculture were estimated to together contribute around $80 \%$ to the TP loading to the Dongting Lake in 2010. Similarly, Strokal et al. (2016) find that animal manure contributed more than $75 \%$ to total dissolved phosphorus inputs to rivers in some sub-basins of the large rivers in China (including the Dongting Lake watershed) in 2000. In addition, Bai et al. (2016) reported that animal production contributed around $70 \%$ to the TP input to rivers in China in 2010. As explained in the "Methods" section, animal production in China has been shifted from household scale to industrial farm scale since the 1990 s, leading to the transformation of livestock husbandry from a diffuse nutrient source to a point source in large parts of the country.

\section{Conclusions}

This study used an export coefficient model and the Dillon-Rigler model to estimate the contributions from different sub-watersheds and sources to the TP export from the Dongting Lake watershed and the TP loading to the Lake. Among the secondary sub-watersheds of the Dongting Lake watershed, the upper and lower reaches of the Xiang River watershed and the Dongting Lake Area were estimated to be the major contributors to the TP export from the Dongting Lake watershed. Three primary subwatersheds (the Dongting Lake Area, the Xiang River, and the Yuan River watersheds) were estimated to contribute to most of the TP loading from the entire watershed. Livestock husbandry was estimated to be the predominant source among all the anthropogenic sources for the TP export and loading. The total TP loading to the lake should be reduced by $38.6 \%$ of the actual 2010 annual loading so that the lake can meet the Class III standard for lake water quality (in terms of TP concentration). The watershed management policies should particularly target the control of $\mathrm{P}$ emission from livestock husbandry in the Dongting Lake Area and in the Xiang River watershed and from aquaculture in the Dongting Lake Area.

Uncertainties emerging in the modeling process of this study are related to model suitability, coefficients credibility, and a shortage of observed data due to a concise river and lake-monitoring program. Measures, such as bathymetric measurements of the lake, taking more water samples during high water flow in the rainy season, and monitoring small tributaries in the Dongting Lake Area, can help to reduce the uncertainties and provide data for validating the modeling results. Although the modeling results were not validated, the most significant finding of our study reflects the reality of TP pollution in the Dongting Lake watershed.

This study provides knowledge on the spatial distribution and source pattern of TP exports from the Dongting Lake watershed and TP loading to the lake. This knowledge can help the environment managers of the watershed develop measures for $\mathrm{P}$ pollution control and to reduce the eutrophication risk of the Dongting Lake. In addition, the study provides a methodology to identify the key sources and regions of nutrient loading to lakes from complex lake watersheds. Further studies applying the export coefficient model and the Dillon-Rigler model to a wider range of lake watersheds are needed to more widely validate these two methods as tools to support the decision-making process for the water environment management of lake watersheds.

Acknowledgements This research is supported by the National Natural Science Foundation of China (41601556), the Chinese Academy of Sciences (KFJ-EW-ZY-004) and the Ministry of Science and Technology of China (2014ZX07201-011-005). The spatial data describing the boundaries of the Dongting Lake watershed and the subwatersheds were provided by the National Earth System Science Data Sharing Infrastructure (www.geodata.cn). We would like to thank the anonymous reviewers for their valuable comments and suggestions. 


\section{Appendix}

Table 4 The time, scales and sources of the data used in this study

\begin{tabular}{|c|c|c|c|}
\hline Data & Scale & Time & Source \\
\hline \multicolumn{4}{|l|}{ TP sources } \\
\hline Land use map & $\begin{array}{l}\text { Dongting Lake watershed, } \\
90-\mathrm{m} \times 90-\mathrm{m} \text { resolution }\end{array}$ & 2010 & $\begin{array}{l}\text { Research Center for Eco-Environmental Sciences, } \\
\text { Chinese Academy of Sciences }\end{array}$ \\
\hline Urban and rural population & $\begin{array}{l}\text { Districts/counties of the Dongting } \\
\text { Lake watershed }\end{array}$ & 2010 & $\begin{array}{l}\text { Statistical Yearbooks of Hunan and Guizhou Provinces } \\
\text { and Jinzhou Prefecture (2011) }\end{array}$ \\
\hline Cattle number & $\begin{array}{l}\text { Districts/counties of the Dongting } \\
\text { Lake watershed }\end{array}$ & 2010 & $\begin{array}{l}\text { Statistical Yearbooks of Hunan and Guizhou Provinces } \\
\text { and Jinzhou Prefecture (2011) }\end{array}$ \\
\hline Pig number & $\begin{array}{l}\text { Districts/counties of the Dongting } \\
\text { Lake watershed }\end{array}$ & 2010 & $\begin{array}{l}\text { Statistical Yearbooks of Hunan and Guizhou Provinces } \\
\text { and Jinzhou Prefecture (2011) }\end{array}$ \\
\hline $\begin{array}{l}\text { Production volume of } \\
\text { aquaculture }\end{array}$ & $\begin{array}{l}\text { Districts/counties of the Dongting } \\
\text { Lake watershed }\end{array}$ & 2010 & $\begin{array}{l}\text { Statistical Yearbooks of Hunan and Guizhou Provinces } \\
\text { and Jinzhou Prefecture (2011) }\end{array}$ \\
\hline $\begin{array}{l}\text { Industrial wastewater } \\
\text { volume }\end{array}$ & $\begin{array}{l}\text { Districts/counties of the Dongting } \\
\text { Lake watershed }\end{array}$ & 2010 & $\begin{array}{l}\text { Statistical Yearbooks of Hunan and Guizhou Provinces } \\
\text { and Jinzhou Prefecture (2011) }\end{array}$ \\
\hline \multicolumn{4}{|l|}{ Hydrology } \\
\hline $\begin{array}{l}\text { Inflow and outflow water } \\
\text { volume }\end{array}$ & Dongting Lake & 2010 & $\begin{array}{l}\text { Hunan Water Resources Bulletin (2010) http://www. } \\
\text { hnsw.com.cn/Default.aspx (Accessed } 7 \text { October } 2017 \\
\text { ) }\end{array}$ \\
\hline $\begin{array}{l}\text { Accumulated sediment } \\
\text { quantity }\end{array}$ & Dongting Lake & $\begin{array}{l}\text { During } \\
\quad 1951-2- \\
008\end{array}$ & $\operatorname{Tan}(2013)$ \\
\hline Sediment import and export & Dongting Lake & 2009,2010 & $\begin{array}{l}\text { Sediment Bulletin of the Yangtze River (2009 and 2010) } \\
\text { http://www.cjh.com.cn/pages/nsgb.html (Accessed } 7 \\
\text { October 2017) }\end{array}$ \\
\hline Flow volume of tributaries & Dongting Lake & 2010 & $\begin{array}{l}\text { Hunan Water Resources Bulletin (2010) http://www. } \\
\text { hnsw.com.cn/Default.aspx (Accessed } 7 \text { October } 2017 \\
\text { ) }\end{array}$ \\
\hline \multicolumn{4}{|l|}{ Water quality } \\
\hline $\begin{array}{l}\text { Mean annual concentration } \\
\text { of TP at water quality } \\
\text { monitoring sites }\end{array}$ & $\begin{array}{l}\text { Major tributaries of the Dongting } \\
\text { Lake; East, South and West } \\
\text { Dongting Lake }\end{array}$ & 2010 & The Hunan Province Environmental Monitoring Centre \\
\hline \multicolumn{4}{|l|}{ Lake morphometry } \\
\hline Lake surface area & Dongting Lake & 2010 & Yu et al. (2016) and Lai et al. (2012) \\
\hline Boundaries of sub-watersheds & Dongting Lake watershed & - & $\begin{array}{l}\text { National Earth System Science Data Sharing } \\
\text { Infrastructure, http://www.geodata.cn/ (Accessed } 7 \\
\text { October 2017) }\end{array}$ \\
\hline $\begin{array}{l}\text { Boundaries of districts and } \\
\text { counties }\end{array}$ & Dongting Lake watershed & - & $\begin{array}{l}\text { National Geomatics Center of China, http://ngcc.sbsm. } \\
\text { gov.cn/ (Accessed } 7 \text { October 2017) }\end{array}$ \\
\hline Digital Elevation Model & $\begin{array}{l}\text { Dongting Lake watershed, } \\
500-\mathrm{m} \times 500-\mathrm{m} \text { resolution }\end{array}$ & - & $\begin{array}{l}\text { Geospatial Data Cloud, http://www.gscloud.cn/ } \\
\text { (Accessed } 7 \text { October 2017) }\end{array}$ \\
\hline River map & Dongting Lake watershed & - & $\begin{array}{l}\text { National Earth System Science Data Sharing } \\
\text { Infrastructure, www.geodata.cn (Accessed } 7 \text { October } \\
\text { 2017) }\end{array}$ \\
\hline
\end{tabular}




\section{References}

Alexander, R. B., Elliott, A. H., Shankar, U., \& McBride, G. B. (2002). Estimating the sources and transport of nutrients in the Waikato River Basin, New Zealand. Water Resources Research, 38, 1-4.

Bai, Z., Ma, L., Ma, W., Qin, W., Velthof, G. L., Oenema, O., et al. (2016). Changes in phosphorus use and losses in the food chain of China during 1950-2010 and forecasts for 2030. Nutrient Cycling in Agroecosystems, 104, 361-372.

Beaulac, M. N., \& Reckhow, K. H. (1982). An examination of land-use-nutrient export relationships. Water Resources Bulletin, 18, 1013-1024.

Beckert, K. A., Fisher, T. R., O'Neil, J. M., \& Jesien, R. V. (2011). Characterization and comparison of stream nutrients, land use, and loading patterns in Maryland coastal bay watersheds. Water, Air, \& Soil Pollution, 221, 255-273.

Bennett, E. M., Carpenter, S. R., \& Caraco, N. F. (2001). Human impact on erodable phosphorus and eutrophication: A global perspective. Bioscience, 51, 227-234.

Bennion, H., Johnes, P. J., Ferrier, R. C., Phillips, G., \& Haworth, E. Y. (2005). A comparison of diatom phosphorus transfer functions and export coefficient models as tools for reconstructing lake nutrient histories. Freshwater Biology, 50, 1651-1670.

Chen, D., Lu, J., Wang, H., Shen, Y., \& Kimberley, M. O. (2010). Seasonal variations of nitrogen and phosphorus retention in an agricultural drainage river in East China. Environmental Science and Pollution Research, 17, 312-320.

Chen, H., Teng, Y., \& Wang, J. (2013). Load estimation and source apportionment of nonpoint source nitrogen and phosphorus based on integrated application of SLURP model, ECM, and RUSLE: a case study in the Jinjiang River, China. Environmental Monitoring and Assessment, 185, 2009-2021.

Conley, D. J., Paerl, H. W., Howarth, R. W., Boesch, D. F., Seitzinger, S. P., Havens, K. E., et al. (2009). Controlling eutrophication: Nitrogen and phosphorus. Science, 323, 1014-1015.

Cunha, D. G. F., Do Carmo Calijuri, M., \& Dodds, W. K. (2014). Trends in nutrient and sediment retention in Great Plains reservoirs (USA). Environmental Monitoring and Assessment, 186, 1143-1155.

David, G. S., Carvalho, E. D., Lemos, D., Silveira, A. N., \& Dall'Aglio-Sobrinho, M. (2015). Ecological carrying capacity for intensive tilapia (Oreochromis niloticus) cage aquaculture in a large hydroelectrical reservoir in Southeastern Brazil. Aquacultural Engineering, 66, 30-40.

Dillon, P. J., \& Rigler, F. H. (1974). A test of a simple nutrient budget model predicting the phosphorus concentration in lake water. Journal of the Fisheries Research Board of Canada, 31, 1771-1778.

Ding, X., Shen, Z., Hong, Q., Yang, Z., Wu, X., \& Liu, R. (2010). Development and test of the export coefficient model in the upper reach of the Yangtze River. Journal of Hydrology, 383, 233-244.

Dou, H., \& Jiang, J. (2000). The Dongting Lake. Hefei: University of Science and Technology of China Press (in Chinese).

Gao, F. (2014). Research on water environment carrying capacity and control scheme of the typical lake: a case study of the westside of Hongze lake. Dissertation, Nanjing Normal University, Nanjing (in Chinese).

Hou, Y., Burkhard, B., \& Müller, F. (2013). Uncertainties in landscape analysis and ecosystem service assessment. Journal of Environmental Management, 127(Supplement), S117-S131.

Hou, Y., Chen, W., Liao, Y., \& Luo, Y. (2017). Scenario analysis of the impacts of socioeconomic development on phosphorous export and loading from the Dongting Lake watershed, China. Environmental Science and Pollution Research. https://doi.org/10.1007/s11356-017-0138-4.

Hwang, S., Hwang, S., Park, S., \& Lee, S. (2016). Examining the relationships between watershed urban land use and stream water quality using linear and generalized additive models. Water, 8, 155.

Hydrology and Water Resources Survey Bureau of Hunan Province (2010). Hunan Water Resources Bulletin 2010. Changsha: Report, Hunan Provincial Water Resources Department. http://www.hnsw.com.cn/Default.aspx (in Chinese) (Accessed 26 October 2017).

Johansson, T. R., \& Nordvarg, L. (2002). Empirical mass balance models calibrated for freshwater fish farm emissions. Aquaculture, 212, 191-211.

Johnes, P. J. (1996). Evaluation and management of the impact of land use change on the nitrogen and phosphorus load delivered to surface waters: the export coefficient modelling approach. Journal of Hydrology, 183, 323-349.

Johnes, P. J., Foy, R., Butterfield, D., \& Haygarth, P. M. (2007). Land use scenarios for England and Wales: evaluation of management options to support 'good ecological status' in surface freshwaters. Soil Use and Management, 231, 176-194.

Kirchner, W. B., \& Dillon, P. J. (1975). An empirical method of estimating the retention of phosphorus in lakes. Water Resources Research, 11, 182-183.

Lai, X., Jiang, J., \& Huang, Q. (2012). Pattern of impoundment effects and influencing mechanism of Three Gorges Project on water regime of Lake Dongting. Journal of Lake Sciences, 24, 178-184 (in Chinese).

Li, X., Lu, J., Qian, M., Wang, X., Fan, Z., \& Wang, S. (2014). Study on pollution loading and water environmental capacity in watershed - a case study of Taiping Lake Basin, Anhui Province, China. China Environmental Science, 34, 20632070 (in Chinese).

Liu, R., Yang, Z., Shen, Z., Yu, S. L., Ding, X., Wu, X., et al. (2009). Estimating nonpoint source pollution in the upper Yangtze River using the export coefficient model, remote sensing, and geographical information system. Journal of Hydraulic Engineering ASCE, 135, 698-704.

Liu, B., Liu, H., Zhang, B., \& Bi, J. (2013). Modeling nutrient release in the Tai Lake Basin of China: Source identification and policy implications. Environmental Management, 51, 724-737.

Liu, R., Dong, G., Xu, F., Wang, X., \& He, M. (2015). Spatialtemporal characteristics of phosphorus in nonpoint source pollution with grid-based export coefficient model and geographical information system. Water Science and Technology, 71, 1709-1717.

Ma, G., \& Wang, S. (2015). Temporal and spatial distribution changing characteristics of exogenous pollution load into Dianchi Lake, Southwest of China. Environmental Earth Sciences, 74, 3781-3793.

Ma, X., Li, Y., Zhang, M., Zheng, F., \& Du, S. (2011). Assessment and analysis of non-point source nitrogen and phosphorus 
loads in the Three Gorges Reservoir Area of Hubei Province, China. Science of the Total Environment, 412-413, 154-161.

Ma, X., Li, Y., Li, B., Han, W., Liu, D., \& Liu, X. (2016). Evaluation of nitrogen and phosphorus loads from agricultural nonpoint source in relation to water quality in tThree Gorges Reservoir Area, China. Desalination and Water Treatment, 57, 20985-21002.

Matias, N., \& Johnes, P. J. (2012). Catchment phosphorous losses: an export coefficient modelling approach with scenario analysis for water management. Water Resources Management, 26, 1041-1064.

Mhlanga, L. (2013). The application of a phosphorus mass balance model for estimating the carrying capacity of Lake Kariba. The Turkish Journal of Veterinary and Animal Sciences, 37, 316-319.

Ministry of Environmental Protection of China and General Administration of Quality Supervision, Inspection and Quarantine of China (2002a). Discharge standard of pollutants for municipal wastewater treatment plant (GB189182002). Standard, released on 24 December 2002 (in Chinese).

Ministry of Environmental Protection of China and General Administration of Quality Supervision, Inspection and Quarantine of China (2002b). Environmental quality standards for surface water (GB3838-2002). Standard, released on 28 April 2002 (in Chinese).

Mourad, D. S. J., Van Der Perk, M., \& Piirimäe, K. (2006). Changes in nutrient emissions, fluxes and retention in a north-eastern European lowland drainage basin. Environmental Monitoring and Assessment, 120, 415-448.

OECD. (1982). Eutrophication of waters: monitoring, assessment and control. Paris: Organization for Economic.

Omernik, J. M. (1976). The influence of land use on stream nutrient levels. Report. Washington D.C: U.S. Environmental Protection Agency.

Pang, Y., \& Lu, G. (2010). The theory and application of the calculation of water environment carrying capacity. Beijing: Science Press (in Chinese).

Pulatsü, S., \& Aydin, F. (1997). Water quality and phosphorus budget of Mogan Lake, Turkey. Acta Hydrochimica et Hydrobiologica, 25, 128-134.

Qin, D., Huang, Z., Luo, Y., Bi, J., Xiao, C., Huang, Y., et al. (2011). Pollution control regionalization and countermeasures in Dongting Lake Area. Research of Environmental Sciences, 24, 748-755 in Chinese.

Reckhow, K. H., \& Simpson, J. T. (1980). A procedure using modeling and error analysis for the prediction of lake phosphorus concentration from land use information. Canadian Journal of Fisheries and Aquatic Sciences, 37, 1439-1448.

Rodrigues-Filho, J., Degani, R., Soares, F., Periotto, N., Blanco, F., Abe, D., et al. (2015). Alterations in land uses based on amendments to the Brazilian Forest Law and their influences on water quality of a watershed. Brazilian Journal of Biology, $75,125-134$.

Statistical Burean of Guizhou Province (2011). Statistical Yearbook of Guizhou Province 2011. Beijing: China Statistics Press.

Statistical Burean of Hunan Province (2011). Statistical Yearbook of Hunan Province 2011. Beijing: China Statistics Press.

Statistical Burean of Jingzhou Prefecture (2011). Statistical Yearbook of Jinzhou Prefecture 2011. Beijing: China Statistics Press.
Strokal, M., Ma, L., Bai, Z., Luan, S., Kroeze, C., Oenema, O., et al. (2016). Alarming nutrient pollution of Chinese rivers as a result of agricultural transitions. Environmental Research Letters, 11.

Tan, H. (2013). The succession and reason analysis of hydrological environment in the Dongting Lake in recent 50 years. Dissertation, Hunan Agricultural University, Changsha (in Chinese).

The Office of the Leading Group on the First National Census on Pollution Sources. (2007). Handbook on the first national census on pollution sources. Beijing: Report, China's State Council in Chinese.

Tian, Z., Zheng, B., Wang, L., Li, L., Wang, X., Li, H., et al. (2017). Long term (1997-2014) spatial and temporal variations in nitrogen in Dongting Lake, China. PLoS One, 12.

Vollenweider, R. A. (1975). Input-output models: with special reference to the phosphorus loading concept in limnology. Schweizerische Zeitschrift für Hydrologie, 37, 53-84.

Wang, J., Shao, J., Wang, D., Ni, J., \& Xie, D. (2015). Simulation of the dissolved nitrogen and phosphorus loads in different land uses in the Three Gorges Reservoir Region-based on the improved export coefficient model. Environmental Science: Processes \& Impacts, 17, 1976-1989.

Wang, Y., He, B., Duan, W., Li, W., Luo, P., \& Razafindrabe, B. (2016). Source apportionment of annual water pollution loads in river basins by remote-sensed land cover classification. Water, 8, 361.

Wilkins, R. J. (2008). Eco-efficient approaches to land management: a case for increased integration of crop and animal production systems. Philosophical Transactions of the Royal Society B-Biological Sciences, 363, 517-525.

Winter, J. G., \& Duthie, H. C. (2000). Export coefficient modeling to assess phosphorus loading in an urban watershed. Journal of the American Water Resources Association, 36, 10531061.

Wu, L., Long, T., Liu, X., \& Guo, J. (2012). Impacts of climate and land-use changes on the migration of non-point source nitrogen and phosphorus during rainfall-runoff in the Jialing River Watershed, China. Journal of Hydrology, 475, 26-41.

Wu, L., Gao, J., Ma, X., \& Li, D. (2015). Application of modified export coefficient method on the load estimation of non-point source nitrogen and phosphorus pollution of soil and water loss in semiarid regions. Environmental Science and Pollution Research, 22, 10647-10660.

Yang, L., Qin, B., Hu, W., Luo, L., \& Song, Y. (2007). The atmospheric deposition of nitrogen and phosphorus nutrients in Taihu Lake. Oceanologia et Limnologia Sinica, 38, 104110 (in Chinese).

Yilmaz, G. B., \& Sivri, N. (2014). Estimation of nutrient loads in Ergene basin through GIS. Fresenius Environmental Bulletin, 23, 3212-3221.

Yu, H., Zhang, L., Yan, S., Li, H., \& Xu, J. (2011). Atmospheric wet deposition characteristics of nitrogen and phosphorus nutrients in Taihu Lake and contributions to the lake. Research of Environmental Sciences, 24, 1210-1219 (in Chinese).

Yu, D., Yu, S., He, Q., Li, C., \& Wei, C. (2016). Monitoring of Dongting Lake atrophy in the past 100 years by combining historical map and remote sensing technology. Remote Sensing for Land \& Resources, 28, 116-122 (in Chinese). 
Zhang, S. (2007). The research on assessment, prediction and restoration of Dongting Lake ecosystem based on health theory. Dissertation, Hunan University, Changsha (in Chinese).

Zhao, G., Tian, P., Mu, X., Gao, J., Li, H., \& Zhang, Z. (2012). Estimation of nitrogen and phosphorus loads in the Xitiaoxi catchment using PCRaster software. Advances in Water Science, 23, 80-86 (in Chinese).

Zheng, D., Wang, X., Xie, S., Duan, L., \& Chen, D. (2014). Simulation of atmospheric nitrogen deposition in China in 2010. China Environmental Science, 34, 1089-1097 (in Chinese). 